\title{
The Sustainability Status of Partnership of Palm Oil Plantations
}

\author{
Wilson Daud ${ }^{1}$, Sri Panuntun ${ }^{2}$ \\ ${ }^{1}$ Faculty of Agricultural, University of Palangka Raya \\ Jalan H. Timang, Kampus Unpar Tunjung Nyaho, Palangka Raya 73112 Indonesia \\ 2 Faculty of Health Sciences, University of Respati Yogyakarta \\ Jalan Laksda Adisucipto Km. 6,3 Depok Sleman,Yogyakarta, Indonesia \\ Correspondence e-mail: wildapraya@yahoo.com; ichaku06@yahoo.com
}

Received: March 2015; Accepted: October 2015

\begin{abstract}
One of existence determining factor of PBS palm oil is a harmonious relation with communities surroundings, thus the partnership between the palm oil plantation with the farmers surroundings is one of effort which has created the harmonization in palm oil plantation. The objective of the article is to express the sustainability of each pattern of palm oil PBS partnership, and this partnership form gives the sustainability advantages for the farmer and palm oil PBS in Central Kalimantan. The article used quantitative method through the survey approach, primary data and secondary data. The article result there are three main patterns of palm oil plantation partnership in Central Kalimantan, they are MSA, KKPA, and IGA. IGA has value as a form which has degree of continuing that higher than MSA and KKPA, thus make IGA can be the reference in frame of PBS palm oil partnership in Central Kalimantan with keeping the superiority and improving the weaknesses.
\end{abstract}

Keywords: partnership, palm oil, sustainability, local economic JEL Classification: A13, Q13, Q28

\section{Keberlanjutan Status Kemitraan dalam Perkebunan Kelapa Sawit}

\begin{abstract}
Abstrak
Salah satu faktor yang menentukan keberadaan minyak sawit PBS adalah hubungan yang harmonis dengan masyarakat sekitar, sehingga kemitraan antara perkebunan kelapa sawit dengan petani sekitar merupakan salah satu usaha yang telah menciptakan harmonisasi di perkebunan kelapa sawit. Tujuan penelitian ini untuk mengungkapkan keberlanjutan dari setiap pola kemitraan minyak sawit PBS, dan bentuk kemitraan ini memberikan keuntungan yang berlanjut untuk petani dan minyak sawit PBS di Kalimantan Tengah. Penelitian ini menggunakan metode kuantitatif melalui pendekatan survei, data primer, dan data sekunder. Hasil penelitian mengungkap adanya tiga pola utama kemitraan dalam perkebunan kelapa sawit, yaitu MSA, KKPA, dan IGA. IGA memiliki nilai sebagai bentuk dengan tingkat keberlanjutannya lebih tinggi daripada MSA dan KKPA, dengan demikian IGA dapat menjadi acuan dalam kerangka kemitraan minyak sawit PBS di Kalimantan Tengah dengan tetap menjadi keunggulan dan memperbaiki kelemahan
\end{abstract}

Kata kunci: perkongsian, minyak kelapa sawit, keberlanjutan, ekonomi daerah Klasifikasi JEL: A13, Q13, Q28

\section{Introduction}

Palm oil plantations are one of those plants, which are crucial for the plantation subsector, for several reasons, such as (1) the production of palm oil as raw material for cooking oil is a source of food, (2) palm oil plantations has been providing employment opportunities, (3) obtained the export value of palm oil in the form of Crude Palm Oil (CPO) and provide income for farmers, and (4) palm oil is a perennial plant tree-shaped (tree crops) can absorb greenhouse 


\section{Jurnal Ekonomi Pembangunan, 16 (2), Desember 2015, 174-180}

gases such as $\mathrm{CO}_{2}$ and able to produce $\mathrm{O}_{2}$ and other environmental services such biodiversity conservation or eco-tourism (Agiculture Department, 2007).

In 2012 the area of oil palm in Central Kalimantan area of 1,164,009 ha and is dominated by the PBS 984736 ha (84.60\%). In addition some of these roles, it is no less important is that oil palm plantations are expected to empower the surrounding community in order to increase household income. Local regulation (PERDA) of Central Kalimantan No. 5 of 2011 about Sustainable Management of Plantations, section 1 and subsection 29, that "PBS palm oil in Central Kalimantan required to implement the plantation business partnerships, namely a harmonious work relationship and to synergy and mutual benefit, respect, responsible, strengthen, and interdependence between the company and planters, employees, surrounding communities, including the indigenous". But Ngando, et. al. (2011), Dimelu and Anyaiwe (2011), said that the implementation of the partnership business carried out by palm oil companies showed lower earnings and higher loan interest will result in farmers always have a debt to the company. Dependence of farmers debts psychologically effects for the community, so often lead to conflict because there is no other way to fight the company, except with the emotional and physical conflict (Basiron and Weng, 2004; Turner and Foster, 2009).

Based on the importance of the role of palm oil plantations, the difference between facts and expectations as well as the PERDA of Central Kalimantan which has been described previously, deemed it is necessary to be construct develop a partnership to know the sustainability of palm oil plantations partnership in Central Kalimantan as a reference for the Central Kalimantan provincial government to develop the policies more about a partnership between PBS palm oil with neighboring farmers, and as a solution for farmers and companies along with other partners so that palm oil plantations can exist and sustainable.

The existence of PBS palm oil is determined by social or environmental factors surrounding communities so that PBS had to build partnerships with the community. Partnership is expected to increase the income of farmers and local economic development. Thus it id needed to build a partnership that benefits all parties. The partnership pattern that was built by PBS palm oil is an implementation of Local Regulationof Central Kalimantan Province No. 5 of 2011. The problems in this article are: (1) how the sustainability index of each partnership pattern between PBS palm oil with communities and other stakeholders; and (2) which partnership pattern that is more suitable to be applied in Central Kalimantan.

The objectives of this research are: (1) To disclose on how the sustainability of each partnership pattern which is implemented by PBS palm oil in Central Kalimantan; (2) To establish a partnership pattern that provides sustainable benefits for farmers and companies in the development of palm oil plantations in Central Kalimantan.

Results of this research are very useful for:

(1) To create the harmonization between PBS palm oil, communities and other stakeholders in order to bring a sustainable plantation development. (2) As inputof Central Kalimantan Government policies to establish a partnership pattern that is suitable to be applied in the development of palm oil plantations in Central Kalimantan.

\section{Research Method}

This research uses a quantitative method through survey approach, that is a research to get the facts and get to know the problems and justification of the practices that are ongoing by a particular unit in a particular place and time with the sample (Way and Pahl, 2001; Magilvy and Thomas, 2009).

The sample of this research includes PBS palm oil cooperations, Lembaga Keuangan Mikro (LKM) and farmers. PBS palm oil sample selected intentionally (purposive) based on a partnership pattern that has been done in Central Kalimantan. Samples of cooperations, LKM and farmers is establish according to snow ball based on previous samples or according to the partners built by PBS palm oil concerned. Then the next smallest sample is a sample of households in units of one family or household 
Avalaible online at http://journals.ums.ac.id

Jurnal Ekonomi Pembangunan, 16 (2), Desember 2015, 174-180

Table 1. Category of Sustainability Partnership Status

\begin{tabular}{cl}
\hline Sustainability Indices & Sustainability Status \\
\hline $0-25$ & Poor / bad (unsustainable) \\
$26-50$ & Less / poor (less sustainable) \\
$51-75$ & Adequate / adequate (reasonably sustainable) \\
$76-100$ & Good / good (sustainable) \\
\hline Source: Thamrin, et al., (2007); Suyitman, et. al., (2009); Nagiah and Azmi (2012)
\end{tabular}

Source: Thamrin, et al., (2007); Suyitman, et. al., (2009); Nagiah and Azmi (2012)

(KK) by 20 households in each partnership pattern.

Data needed consists of primary and secondary data. Primary data sourced from the PBS palm oil, cooperatives, LKM and communities/farmers. Secondary data sourced from Dinas Perkebunan Provinsi Kalimantan Tengah, Dinas Perkebunan selected districts, Badan Pusat Statistik of Central Kalimantan, and Badan Pusat Statistik selected districts. Primary data was collected through questionnaires filled out by respondents. Information that is deemed necessary to do a live interview and Focus Group Discussions (FGD). Secondary data was collected through a document available at the relevant data source by first making a list of data requirements.

Partnership which matched to be applied in the development of palm oil plantations using comparative approach between each partnership pattern. The partnership pattern that is suitable is a partnership pattern which has the highest sustainability index. The weakness of a partnership pattern that has the highest sustainability index is detected by the leverage of the attribute. Sustainability index and the leverage of attributes can be determined by methods Multi Dimensional Scaling (MDS) assisted with the program Microsoft Office Excel Add-Ins RAPFISH.

This research uses 5 dimensions, namely economic dimension (9 attributes), the social dimension (8 attributes), the environment dimension (9 attributes), the transparency dimension (12 attributes), and the diffusion of innovation dimension (9 attributes). Sustainability index projected on the horizontal line in ordinal scale between two point of extremes, that is bad and good extreme points given index value between 0-100 percent. Category of sustainability of bussiness partnership status are presented in Table 1.

\section{Results and Discussion}

\subsection{Sustainability Index of Each Partnership Pattern}

The partnership pattern that is applied by PBS palm oil in Central Kalimantan consists of three main patterns, they are Manajemen Satu Atap (MSA), Kredit Koperasi Primer untuk Anggota (KKPA), and Income Generating Activity (IGA). Based on the data processing using the Multi Dimensional Scaling (MDS) assisted with the program Microsoft Office Excel Add-Ins RAPFISH, obtained sustainability index of each partnership pattern as follows:

\subsubsection{Manajemen Satu Atap (MSA)}

Overall sustainability index MSA pattern is $43.59 \%$. The most dominant attribute is technical training for partners. Based on the sustainability index of each dimension, sustainability status pattern of MSA could be determined for each dimension as in Table 2.

Table 2. Status of Sustainability For Each Dimension on MSA Pattern

\begin{tabular}{clc}
\hline No. & Dimension & $\begin{array}{c}\text { Sustainability } \\
\text { Index (\%) }\end{array}$ \\
\hline 1. & Economic & 54,79 \\
2. & Social & 35,44 \\
3. & Environment & 42,95 \\
4. & Transparency & 69,74 \\
5. & Diffusion of & 15,02 \\
\hline The combined five & Innovations & 43,59 \\
\multicolumn{2}{l}{ dimensions }
\end{tabular}




\section{Jurnal Ekonomi Pembangunan, 16 (2), Desember 2015, 174-180}

Table 2 shows that the sustainability status of the pattern of MSA in terms of each dimension is less sustainable because it is on the index interval 26 - 50. The sustainability index for each dimension can be showed in pancagonal diagrammatic form as in Figure 1.

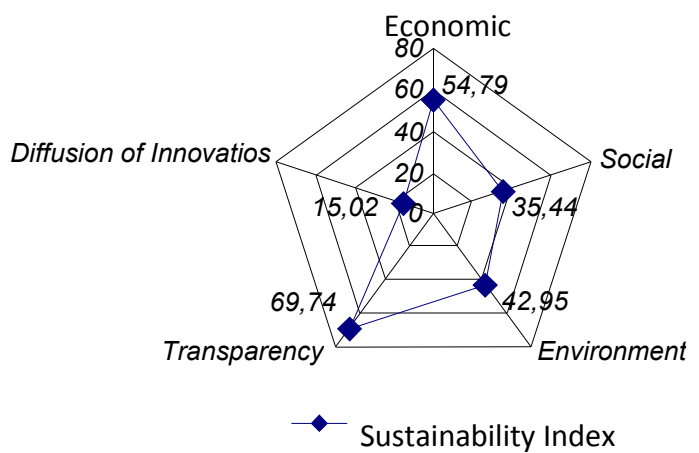

Figure 1. Diagram Pancagonal MSA Pattern Sustainability Partnership

\subsubsection{Kredit Koperasi Primer untuk Anggota (KKPA)}

Overall sustainability index KKPA patterns is $32.43 \%$. The most dominant attribute is the involvement of company to help members (cooperation) for access to the means of production after the loan paid. Based on the sustainability index of each dimension, sustainability status could be determined KKPA pattern of each dimension as in Table 3.

Table 3. Sustainability Status of each dimension on KKPA Pattern

\begin{tabular}{clc}
\hline No. & \multicolumn{1}{c}{ Dimension } & $\begin{array}{c}\text { Sustainability } \\
\text { Index (\%) }\end{array}$ \\
\hline 1. & Economic & 48,44 \\
2. & Social & 31,45 \\
3. & Environment & 48,21 \\
4. & Transparency & 34,03 \\
5. & Diffusion of Innovations & 00,00 \\
\hline The combined five dimensions & 32,43
\end{tabular}

Source: Primary Data are Processed (2014)

Table 3 shows that the sustainability status on KKPA pattern is evaluated from each dimension is less sustainable because it is on the index interval $26-50$. The sustainability index of each dimension can be illustrated in form of pancagonal diagram as in Figure 2.

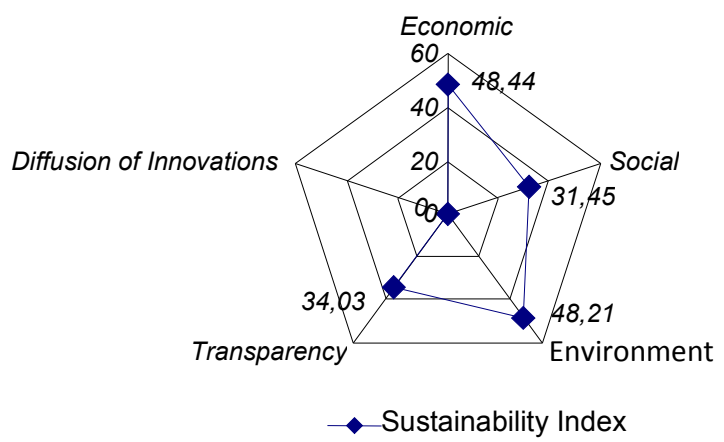

Figure 2. Sustainability Pancagonal Diagram on KKPA Pattern

\subsubsection{Income Generating Activity (IGA)}

Overall sustainability index IGA pattern is $75.54 \%$. The most dominant attribute is the full involvement of partner members in garden maintenance. Based on the sustainability index of each dimension, sustainability status could be determined IGA pattern eof each dimension as in Table 4.

Table 4. Status of Sustainability for Each Dimension on IGA Pattern

\begin{tabular}{clc}
\hline No. & \multicolumn{1}{c}{ Dimension } & $\begin{array}{c}\text { Sustainability } \\
\text { Index (\%) }\end{array}$ \\
\hline 1. & Economic & 72,75 \\
2. & Social & 81,70 \\
3. & Environment & 55,75 \\
4. & Transparency & 100,00 \\
5. & Diffusion of & 67,52 \\
\hline The combined five & 75,54 \\
dimensions & \\
\hline
\end{tabular}

Source: Primary Data are Processed (2014)

Table 4 shows that the sustainability status on KKPA pattern is evaluated from each dimension is quite sustainable because it is on the index interval $51-75$. The sustainability index of each dimension can be illustrated in 
the form of pancagonal diagram as in Figure 3.

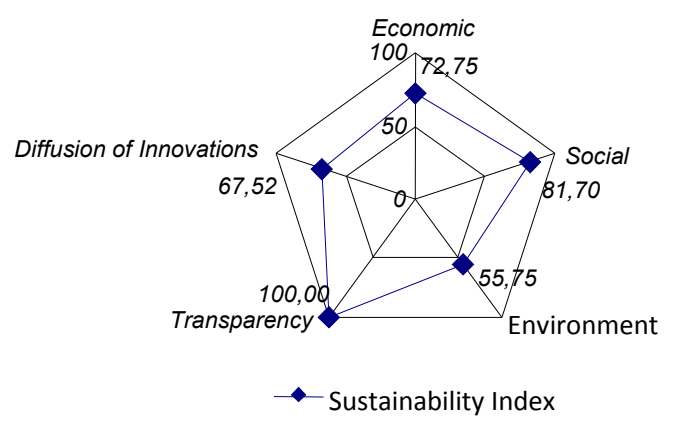

Figure 3. Sustainability Pancagonal Diagram on IGA PAttern

\subsection{The Best Palm Oil Plantation Partnership Pattern}

Comparison between some patterns of partnership in the development of palm oil plantations in Central Kalimantan, include the pattern of MSA, KKPA and IGA. Comparison is done on the basis of the sustainability index in Table 5 .

Table 5 shows the status of sustainability in dimension of the economic, social, environmental, transparency and diffusion of innovation, IGA pattern has the advantage of an index or the higher index, followed by MSA and KKPA patterns. Therefore, the best pattern which conducted by palm oil plantation companies in building a community garden is IGA pattern. However, it does not mean the pattern has no weaknesses. Weakness seen primarily on the environmental dimension and the diffusion of innovation. Furthermore three pattern of sustainability index mentioned above can be described in the form of trigonal diagram as in Figure 4.

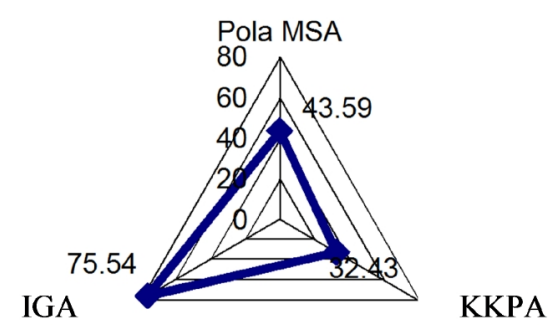

Figure 4. Sustainability Trigonal Diagram on Palm Oil Partnership Pattern

Disadvantages and advantages IGA pattern is detailed and descriptive as follows:

Weaknesses: (a) Farmers often less serious in the maintenance of the garden before the produce time, because while working to fill the needs of the family, although information from management company that farmers are given the opportunity to propose the burden of the Cost of Living (COL). There are still many farmers who do not know that the COL could be proposed to the company. (b) Farmers still face difficulties to obtain fertilizer with a guaranteed quality, while LKM established companies only sell non-subsidized fertilizer. Though LKM have established a demonstration plot to compare the effectiveness of the use of fertilizer subsidies with non-subsidized fertilizer. (c) The average of productivity of farmers' lands is about 0.8 from productivity garden companies, because farmers do themselves. (d) There is chairman of the group of farmers who implement its functions as a middleman. (e) The people who have a sedentary job (full time) and not being able to get hired labor will feel less attractive. (f) There are farmers who are less pay attention to the maintenance of the plants thus make it in low

Table 5. Sustainability Index for Each Pattern According Dimensions

\begin{tabular}{clccc}
\hline \multirow{2}{*}{ No. } & \multicolumn{2}{c}{ Dimension } & \multicolumn{3}{c}{ Sustainability Index (\%) } \\
\cline { 3 - 5 } & & MSA Pattern & KKPA Pattern & IGA Pattern \\
\hline 1. & Economic & 54,79 & 48,44 & 72,75 \\
2. & Social & 35,44 & 31,45 & 81,70 \\
3. & Environment & 42,95 & 48,21 & 55,75 \\
4. & Transparency & 69,74 & 34,03 & 100,00 \\
5. & Diffusion of Innovations & 15,02 & 00,00 & 67,52 \\
\hline \multicolumn{2}{l}{ The combined five dimensions } & 43,59 & 32,43 & 75,54 \\
\hline
\end{tabular}

Source: Primary Data are Processed (2014) 


\section{Jurnal Ekonomi Pembangunan, 16 (2), Desember 2015, 174-180}

productivity (because of the maintenance is done by the farmer's consciousness). (g) There are no active involvement of local government officials, because all of these can be handled and will be the responsibility of the company. Whereas the development of communities is also the responsibility of local governments. (h) Tanggung renteng system could be considered unfair by the farmers who manages his farm well and is able to achieve high productivity.

Excellence: (a) The income of farmers is higher than on another type of partnership, because the farmers could get the salary from their own garden. (b) Farmers obtain assurance TBS selling price is higher than the selling price to middlemen for direct sale at the price at the factory level corresponding with the local government decree. (c) Partnership program prioritized for communities in surrounding villages, should not be followed by the company's workers, thus could reduce the social gap between the community and company workers and ensure a better life to the communities. (d) The number of burden farmers'credir will be light in weight because there is no interest and have been informed in advance about the amount of plafon credit limit which will be borne by the farmers at a price of factors of production according to market price which physically can be witnessed by the farmer according to how many production factor is used. (e) Farmers receive assistance free of charge, because headmen of IGA gardens who provide guidance, counseling, and mentoring is the workers of the company and will get the salary from the company. (f) Applicability of interestfree loan program, because the program is financed by the investment of the company (do not use government programs through commercial banks), thus it does not depend on the presence or absence of government programs. (g) The planning, implementation, and monitoring programs conducted by independent farmers, while the company as a facilitator, so the level of empowerment of farmers is higher. If the company is not involved anymore, farmers can still manage his garden independently. (h) The sense of responsibility of the farmers towards the success of plantation is higher. (i) The management group give to the farmers and their group entirely. (j) Farmers can manage their salary well because the sale of TBS does not paid in cash directly. (k) Members of the group were not able to account for loan installments will paid by all members of the group as a "tanggung renteng", thus the sense of togetherness in the group is always maintained.

\section{Conclusions}

Based on the investigation result of some previous studies have not found research which is related to the sustainability status of partnership of oil palm plantations directly. The research result of Widiarta, Adiwibowo, and Widodo (2011) about the sustainability of organic farming practice among farmers, the research of Suyitman, Sutjahjo and Djulardi (2012) about the sustainability status ofbased area of beef cattle breeding, and the research of Hasim, Sape'i, Budiharsono, and Wardiatno (2012) about the sustainabilitymanagement of lake. Thisresearch concluded that: (1) The total sustainability index of palm oil plantation partnerships on MSA pattern is $43.59 \%$, KKPA pattern is 32,43 and patterns IGApatternis 75.54\%. (2) The partnership pattern of oil palm plantations that have the highest sustainability degree is IGA pattern, thus it can be a reference in the preparation of a partnership pattern of palm oil plantations in Central Kalimantan with retaining the advantages and fix its weakness.

\section{Acknowledgment}

Completed of this article has the support of the parties. Authors say thanked to oil palm plantations in Central Kalimantan which has been a source of data, enumerators, JEP UMS, and other parties have participated until the publication of the article.

\section{References}

Agriculture Department. 2007. Prospects and Direction of Agricultural Development of Palm Oil. Second Edition. Agency for Agricultural Research and Development, Jakarta. 


\section{Jurnal Ekonomi Pembangunan, 16 (2), Desember 2015, 174-180}

Basiron, Y. and C. K. Weng. 2004. The Oil Palm and Its Sustainability. Journal of Oil Palm Research, Vol. 16 No. 1: 1 - 10.

Central Kalimantan Province Regulation No. 5 of 2011 on the Sustainable Management of Plantation Business. Central Kalimantan ProvinceGovernment. Palangka Raya.

Dimelu, M. U. and V. Anyaiwe. 2011. Priorities in Smallholders Oil Palm Producers in Ika Local Government Area og Delta State. Implication for Agricultural Extension Service in Nigeria. World Journal Agricultural, Sci. 7: $117-123$.

Hasim, A. Sape'i, S. Budiharsono, and Y. Wardiatno. 2012. Analysis of Sustainability Status Management in Limbodo Lake, Gorontalo Province. Proceedings of the National Seminar Limnology VI of 2012

Magilvy, J. K. and E. Thomas. 2009. A First Qualitative Project: Qualitative Description Design for Novice Researcher. Journal of the Society for Pediatric Nurses, Vol. 14 (1): 289 - 300.

Nagiah, C. and R. Azmi. 2012. A Review of Smallholder Oil Palm Production: Challenges and Opportunities for Enhancing Sustainability - A Malaysian Perspective. Journal of Oil Palm, Vol. 3: $114-120$.

Ngando, E. G. F., M. E. A. Mpodo, E. E. L. Dikotto, and P. Koona (2011). Assessment of the Quality of Crude Palm Oil from Smallholders in Cameroon. Journal
Stored Production Postharves, Res. 2: 52 58.

Suyitman, S. H. Sutjahjo, C. Herison, dan Muladno. 2009. Status of Regional Sustainability Based Animal Husbandry in Situbondo to Agropolitan Area Development. Journal of Agro Economics (JAE), 27 (2): 165-191.

Suyitman, S.H. Sutjahjo, A. Djulardi. 2012. The Sustainability Status of The Integrated Livestock Area. Journal Animal Husbandry of Indonesia, 14 (1): 318 - 336.

Thamrin, M., S. H. Sutjahjo, C. Herison, danS. Sabiham. 2007. Sustainability Analysis of the Frontier Region of West Kalimantan Malaysia for Agropolitan Area Development. Journal of Agro Economics (JAE), 25 (2): 103-124.

Turner, E. C. and W. A. Foster. 2009. The Impact of Forest Conversion to Oil Palm on Arthropod Abundance and Biomas in Sabah. Journal of Tropical Ecology, Vol. 25: $23-30$.

Way, N. and K. Pahl. 2001. Individual and Contextual Predictor of Perceived Friendship Quality among Ethnic Minority, Low-income Adolescent. Journal of Research on Adolescence, 11: 325 - 349.

Widiarta, A., S. Adiwibowo, Widodo. 2011. Analysis of Sustainability Organic Farming Practise on Farmer. Trandisiplin Journal of Sociology, Communication and Human Ecology, April 2011: 71-89. 